\title{
Land Area Change in Coastal Louisiana from 1932 to 2010
}

By Brady R. Couvillion, John A. Barras, Gregory D. Steyer, William Sleavin, Michelle Fischer, Holly Beck, Nadine Trahan, Brad Griffin, and David Heckman

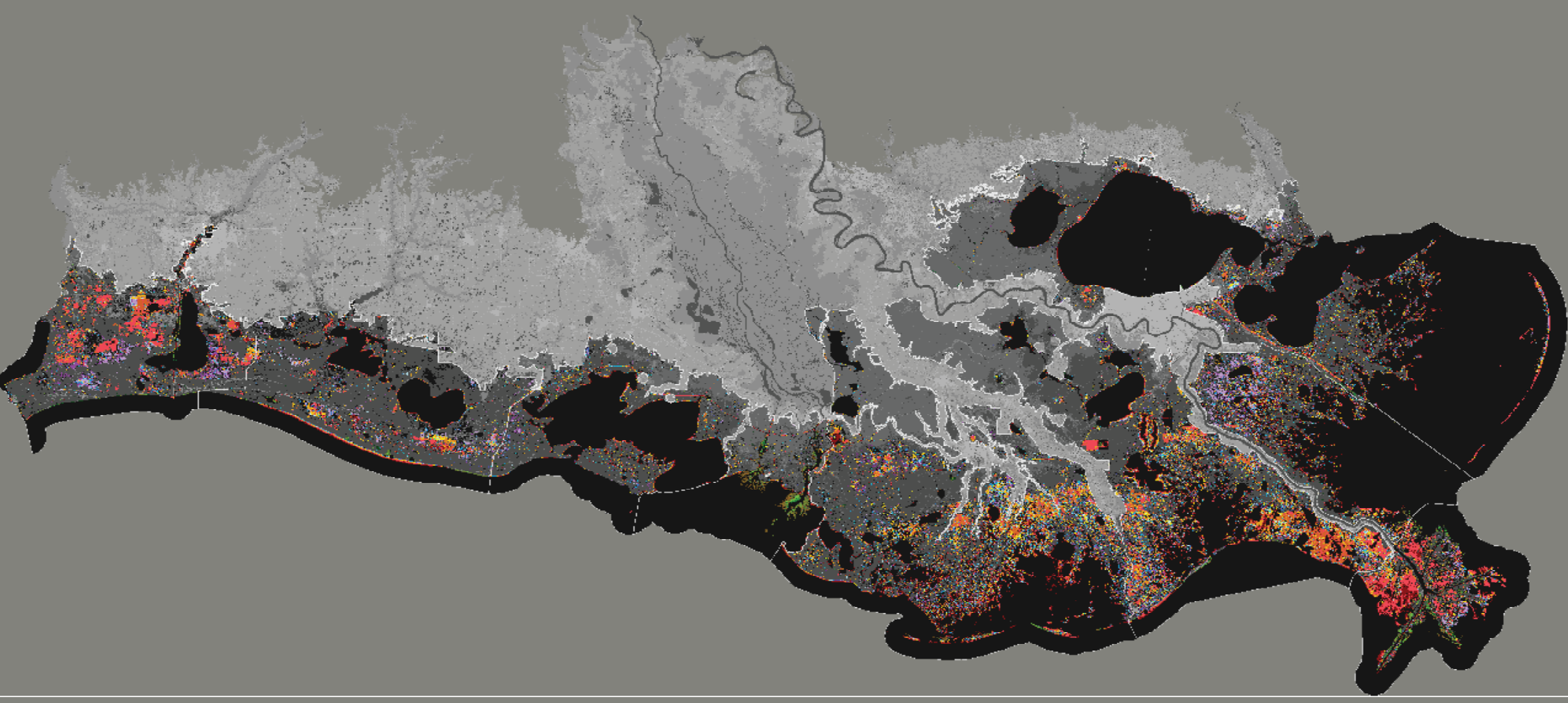

Pamphlet to accompany

Scientific Investigations Map 3164 



\section{Land Area Change in Coastal Louisiana from 1932 to 2010}

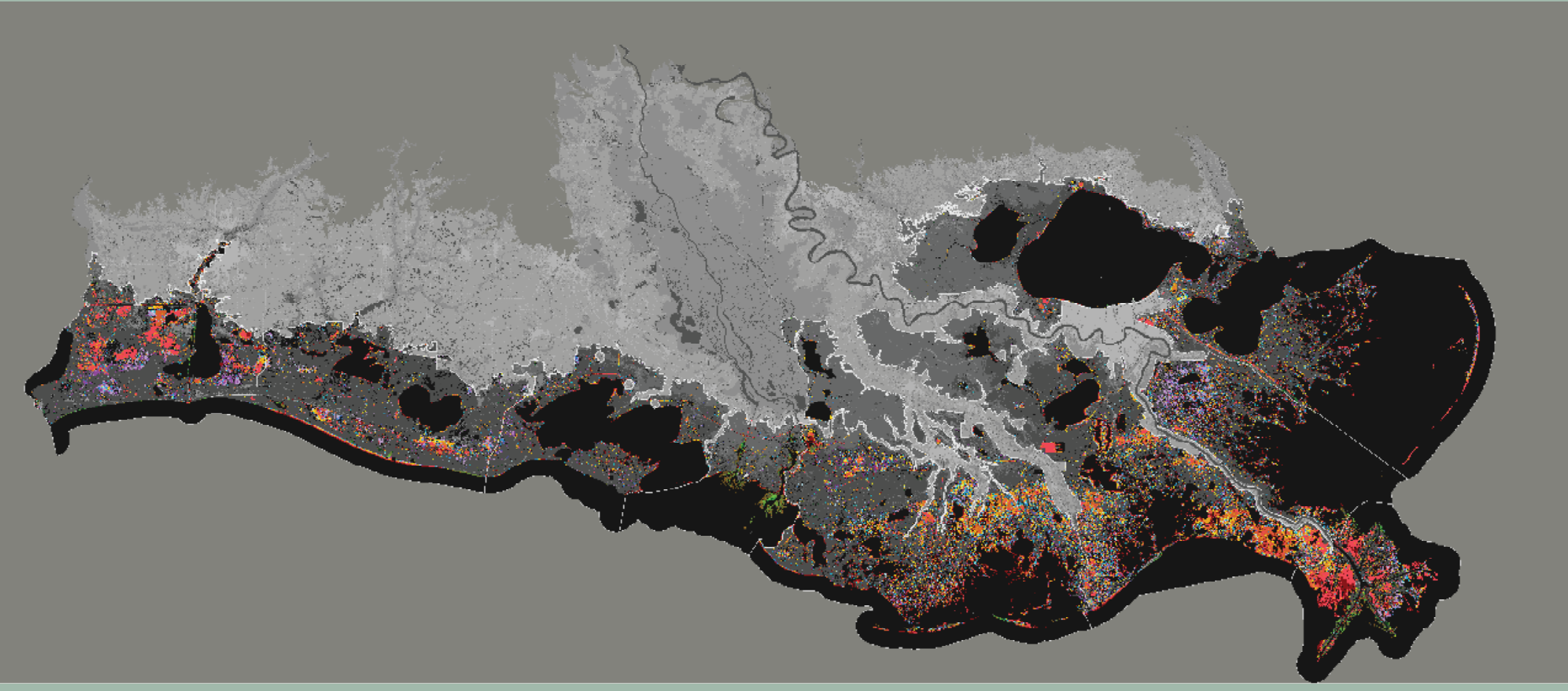

Pamphlet to accompany

Scientific Investigations Map 3164 


\title{
U.S. Department of the Interior KEN SALAZAR, Secretary

\author{
U.S. Geological Survey \\ Marcia K. McNutt, Director
}

\section{U.S. Geological Survey, Reston, Virginia: 2011}

\author{
This and other USGS information products are available at http://store.usgs.gov/ \\ U.S. Geological Survey \\ Box 25286, Denver Federal Center \\ Denver, CO 80225 \\ To learn about the USGS and its information products visit http://www.usgs.gov/ \\ 1-888-ASK-USGS
}

Any use of trade, product, or firm names is for descriptive purposes only and does not imply endorsement by the U.S. Government.

Although this report is in the public domain, permission must be secured from the individual copyright owners to reproduce any copyrighted materials contained within this report.

\section{Suggested citation:}

Couvillion, B.R.; Barras, J.A.; Steyer, G.D.; Sleavin, William; Fischer, Michelle; Beck, Holly; Trahan, Nadine; Griffin, Brad; and Heckman, David, 2011, Land area change in coastal Louisiana from 1932 to 2010: U.S. Geological Survey Scientific Investigations Map 3164, scale 1:265,000, 12 p. pamphlet. 


\section{Contents}

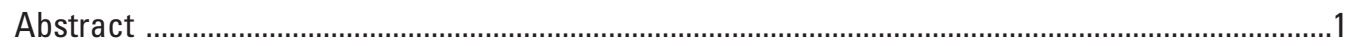

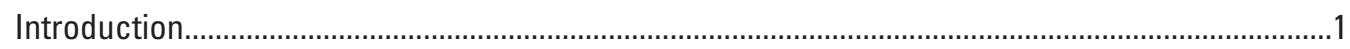

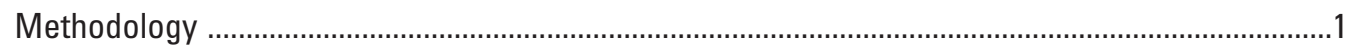

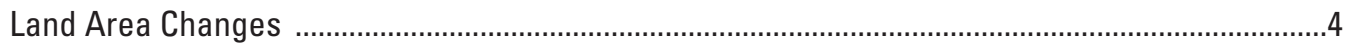

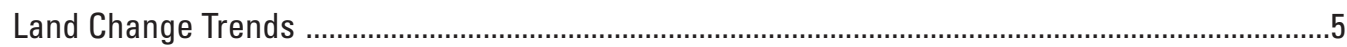

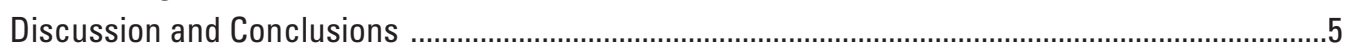

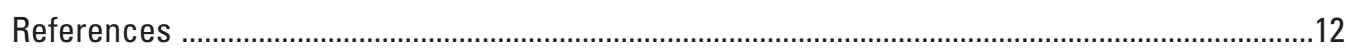

\section{Figures}

1. Map of the study area in coastal Louisiana .................................................................

2. Land area in coastal Louisiana, 1932 to 2010 ..............................................................

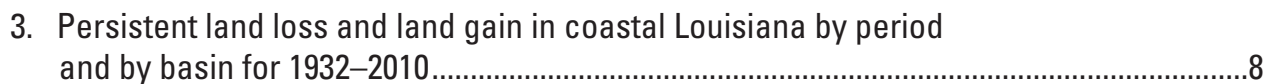

4. Persistent land loss and land gain coastwide across Louisiana by

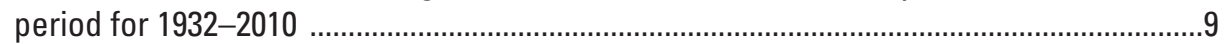

5. Linear regressions of land area change trends coastwide across

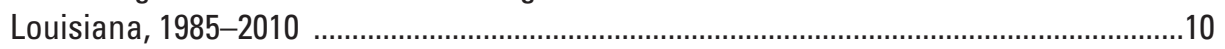

6. Linear regressions of land area change trends in coastal Louisiana by hydrologic basin, 1985-2010.

\section{Tables}

1. Land area in coastal Louisiana by basin, 1932-2010 ......................................................

2. Water levels at selected gages on the date of acquisition for imagery used in the land area estimates

3. Persistent land loss and land gain in coastal Louisiana by basin, 1932-2010 .................6 


\title{
Land Area Change in Coastal Louisiana from 1932 to 2010
}

\author{
By Brady R. Couvillion, John A. Barras, Gregory D. Steyer, William Sleavin, \\ Michelle Fischer, Holly Beck, Nadine Trahan, Brad Griffin, and David Heckman
}

\section{Abstract}

Coastal Louisiana wetlands make up the seventh largest delta on Earth, contain about 37 percent of the estuarine herbaceous marshes in the conterminous United States, and support the largest commercial fishery in the lower 48 States. These wetlands are in peril because Louisiana currently undergoes about 90 percent of the total coastal wetland loss in the continental United States. Documenting and understanding the occurrence and rates of wetland loss are necessary for effective planning, protection, and restoration activities.

The analyses of landscape change presented in this report use historical surveys, aerial data, and satellite data to track landscape changes. Summary data are presented for 19322010; trend data are presented for 1985-2010. These later data were calculated separately because of concerns over the comparability of the 1932 and 1956 datasets (which are based on survey and aerial data, respectively) with the later datasets (which are all based on satellite imagery).

These analyses show that coastal Louisiana has undergone a net change in land area of about $-1,883$ square miles $\left(\mathrm{mi}^{2}\right)$ from 1932 to 2010 . This net change in land area amounts to a decrease of about 25 percent of the 1932 land area. Persistent losses account for 95 percent of this land area decrease; the remainder are areas that have converted to water but have not yet exhibited the persistence necessary to be classified as "loss." Trend analyses from 1985 to 2010 show a wetland loss rate of $16.57 \mathrm{mi}^{2}$ per year. If this loss were to occur at a constant rate, it would equate to Louisiana losing an area the size of one football field per hour.

The use of 17 datasets plus the application of consistent change criteria in this study provide opportunities to better understand the timing and causal mechanisms of wetland loss that are critical for forecasting landscape changes in the future.

\section{Introduction}

The U.S. Geological Survey (USGS) analyzed landscape changes in coastal Louisiana by determining land and water classifications for 17 datasets. These datasets include survey data from 1932, aerial data from 1956, and Landsat
Multispectral Scanner System (MSS) and Thematic Mapper (TM) data from the 1970s to 2010. Previous studies have analyzed land change in coastal Louisiana, but many are out of date, provide data for limited time periods, or lack the temporal frequency necessary to provide information about when the loss occurred. The purpose of this study is to provide updated estimates of persistent land change and historical land change trends for coastal Louisiana and for each hydrologic basin, as defined by the Coastal Wetlands Planning, Protection and Restoration Act Program (n.d.), for the 1932-2010 period of record. The use of 17 datasets plus the application of consistent change criteria in this study provide opportunities to better understand the timing and causal mechanisms of wetland loss that are critical for forecasting landscape changes in the future.

\section{Methodology}

This study analyzed changes in the extent of land in coastal Louisiana by using 17 datasets summarizing land and water areas from 1932 to 2010 (table 1). The datasets were derived from multiple sources including (1) historical survey data (1932); (2) National Wetlands Inventory (NWI) data based on aerial photography (1956); (3) Landsat MultiSpectral Scanner (MSS) data (1973-79); and (4) Landsat Thematic Mapper (TM) satellite imagery classified into land and water categories (1985-2010). Variable data coverage among the 1932 and 1956 datasets and all subsequent data required an assumption of no change in the area of no data coverage (areas with no overlap) in those datasets. No change is assumed in land area from 1932 to 1956 and from 1956 to 1973 in portions of the dataset that occur outside the boundaries of the 1932 and 1956 data coverage. (Refer to figure 1 for more information regarding the areas within the coastal basins to which this assumption was applied.)

The areas missing from the 1932 and 1956 datasets mostly consist of forested wetlands. These areas are historically stable, so the assumption of "no change" is correct in most instances; however, the area and change summaries should only be used with an in-depth understanding of the impacts of this assumption in areas where there are no data in 1932 and 1956. 


\section{Land Area Change in Coastal Louisiana from 1932 to 2010}

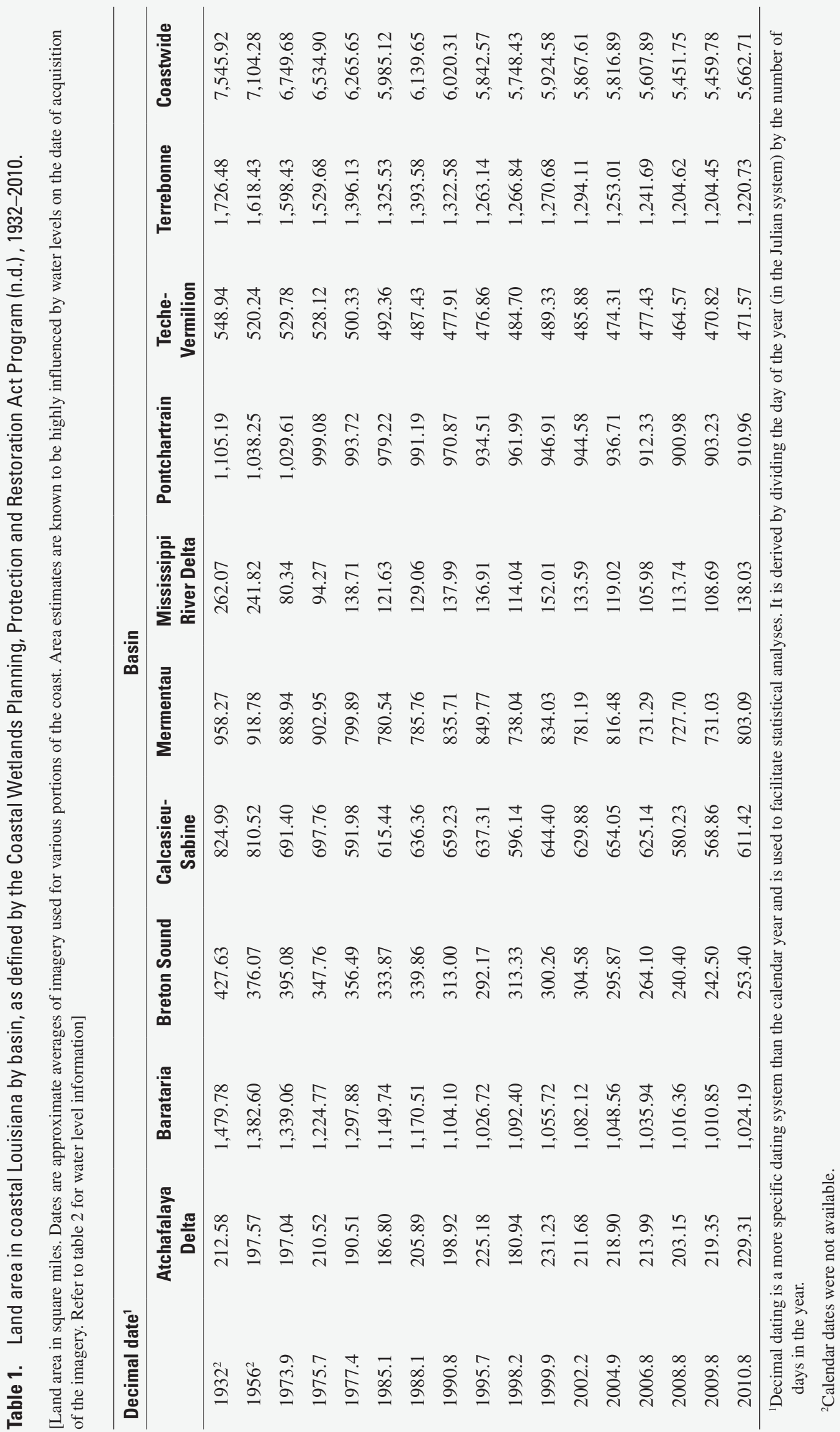




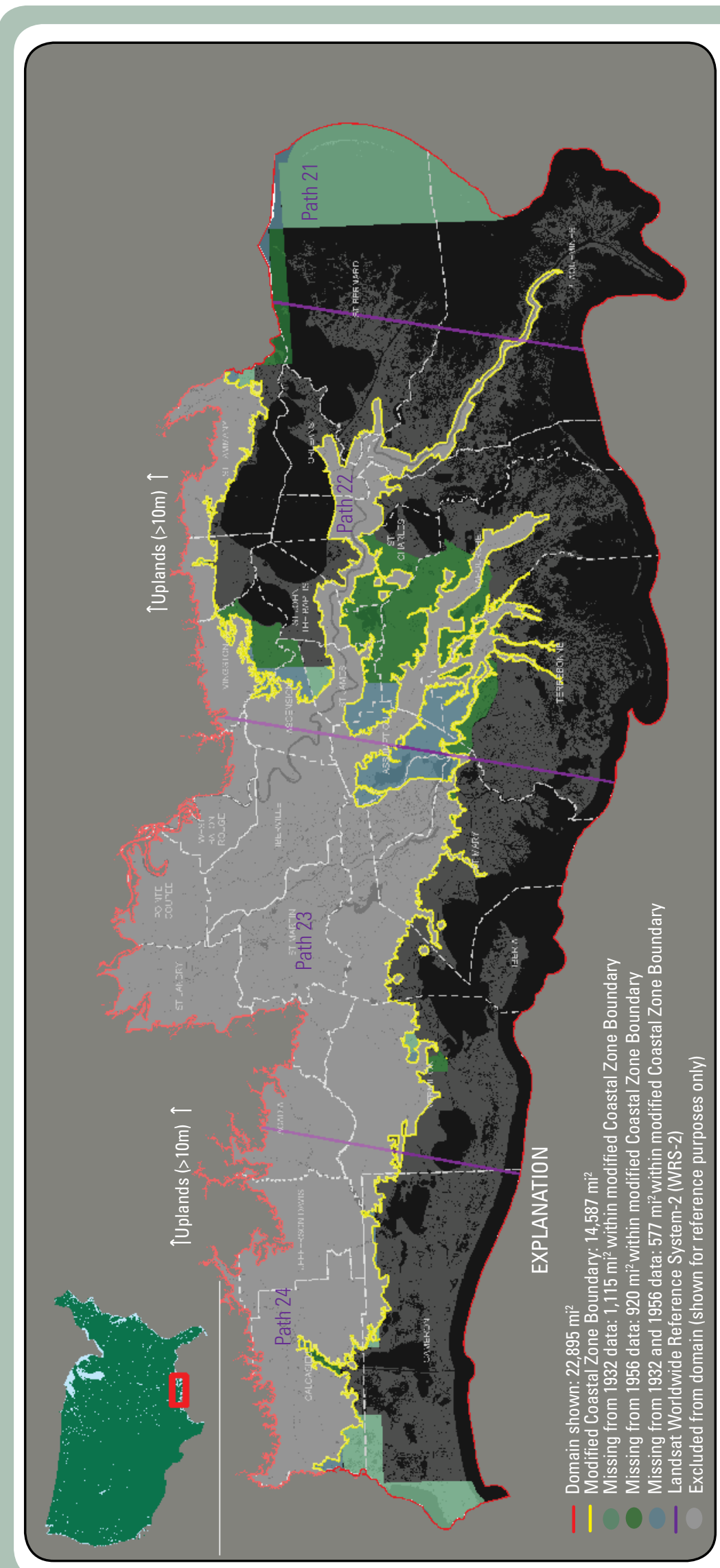

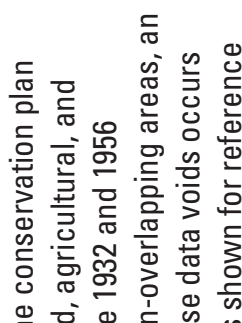

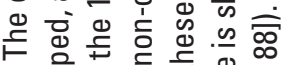

그응

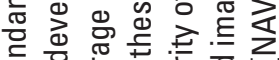

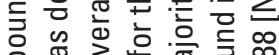

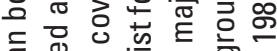

증

可 둉

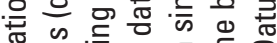

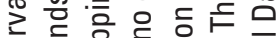

ब $\frac{\pi}{\pi}$ 元

융

芒.

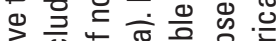

인

(1)

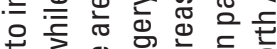

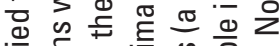

请 흥

ह

उ

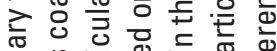

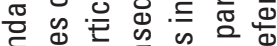

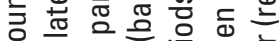

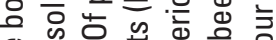

@

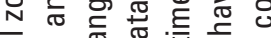

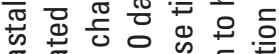

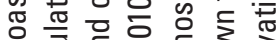

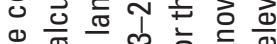

엉

잉

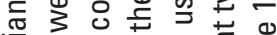

乐

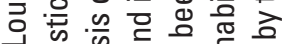

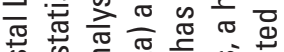

is

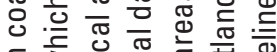

$\subseteq 3$ 频

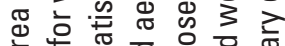

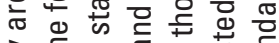

ते 드요에

㝕 N

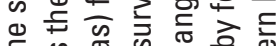

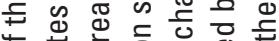

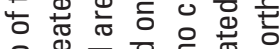

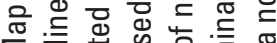

$\sum$ 这券出

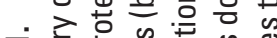

-

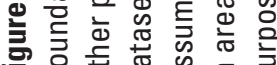


Preprocessing of all datasets included use of ERDAS IMAGINE AutoSync (ERDAS Inc., Norcross, Ga.), a software that uses an automated process to align common landform features between images. To assess change, the geometric registration between datasets must be highly accurate.

Misalignment of features at the same location could produce invalid land change results. This processing step was critical in ensuring that the 1932 and 1956 data aligned with the later satellite-based data. The Landsat MSS data (1973, 1977, and 1979), which have a native 60-meter (m) resolution, were first resampled to a $30-\mathrm{m}$ resolution by using a cubic convolution resampling method to facilitate comparability with later Landsat TM-based data (native 30-m resolution). Conducting this resampling prior to land-water classification is more appropriate than resampling the results of the land-water classification. All satellite imagery data were then classified into land/water categories by using a standard methodology similar to that used in previous studies (Barras, 2006, 2007; Barras and others, 2008).

The methodology used in this study relied heavily on the use of the near infrared band of Landsat data (MSS: Band 7; TM: Band 5) in the early stages of classification. Near infrared (NIR) was selected because the wavelengths in this range, $1.55-1.75$ micrometers, are particularly informative and discriminatory with regard to land and water categories. Supervised and unsupervised classification was then used to account for areas that may be incorrectly classified by the NIR band alone. Areas that need further attention for accurate classification commonly include highly turbid water areas and floating aquatic vegetation. These areas were manually recoded to their appropriate land/water categories by expert analyses.

\section{Land Area Changes}

The resulting land area data were summarized by time period and by basin (table 1 and fig. 2). These analyses show that coastal Louisiana has experienced a net change in land area of approximately $-1,883 \mathrm{mi}^{2}$ from 1932 to 2010. Land area estimates can vary substantially because of environmental variations such as seasonality and, most notably, water-level variations on the date of acquisition (DOA) of the data (Morton and others, 2005; Bernier and others, 2006). (Refer to table 2 for more information regarding the water levels on the DOA for the data used in these analyses.) To reduce some of the errors associated with apparent land change caused by misclassification or transient environmental phenomena, two approaches were utilized. Changes must persist for at least two time periods (of variable length, depending upon availability of cloud-free imagery) following the initial change, and anomalous changes among land and water categories can only occur in less than 20 percent of the remaining datasets. The mapped dataset identifies only these areas of persistent and consistent change (table 3; figs. 3 and 4). For this reason, recent land changes (2008-9 and 2009-10) cannot yet be defined as persistent because data are not available to confirm that these changes have persisted into the two following analysis periods. These unconfirmed changes are instead referred to as "new land investigation areas" and "new water investigation areas" (figs. 3 and 4).

It is important to note that there is a difference between net land area change (table 1 and fig. 1) and persistent losses and gains (table 3, figs. 3, 4). As classification of an area as 
loss or gain depends upon persistence criteria, the amount of area of persistent loss or gain for a particular period can be less than or greater than the net land area change for that period. This occurs because persistent losses in a particular location can be offset by transitory gains in another.

\section{Land Change Trends}

Land change trends by hydrologic basin within the modified coastal zone were calculated solely on the basis of Landsat TM data for 1985-2010 (figs. 5 and 6). Linear regressions were calculated for two time periods, 1985-2004 and 1985-2010, because strong hurricanes in 2005 (Katrina and Rita) and 2008 (Gustav and Ike) greatly impacted both eastern and western coastal Louisiana wetlands. Results show that the Atchafalaya Delta Basin is the only area in coastal Louisiana showing increasing land area (positive land change slope), but the rate of growth in this one basin is not sufficient to offset the losses coastwide, particularly in years of increased hurricane activity. The 2005 and 2008 datasets were excluded to reduce the influence of transitory storm effects. The variability in land area data points around the slope illustrates the influence of various sources of environmental variance or classification error.

\section{Discussion and Conclusions}

This assessment provides a comprehensive analysis of historical trends and rates of land area change in coastal Louisiana. The primary improvement over past efforts is an increased temporal frequency of analysis. This gives scientists the ability to better quantify the amount of wetland loss and the time period in which it was lost. Having this information can allow gradual loss patterns to be distinguished from losses due to episodic events such as hurricanes. The spatial and temporal patterns observed reveal a dynamic landscape changing as a result of the complex and often interactive effects of natural and human-induced processes.

Table 2. Water levels at a selected gage (station ID: 8761724 , located near Grand Isle, La.) on the date of acquisition for imagery used in the land area estimates.

\begin{tabular}{|c|c|c|c|c|c|c|c|c|}
\hline & Path 211 & & Path 221 & & Path 231 & & Path 241 & \\
\hline $\begin{array}{c}\text { Decimal } \\
\text { date }^{2}\end{array}$ & $\begin{array}{l}\text { Calendar } \\
\text { date }\end{array}$ & $\begin{array}{l}\text { Gage height, } \\
\text { in feet }^{3}\end{array}$ & $\begin{array}{l}\text { Calendar } \\
\text { date }\end{array}$ & $\begin{array}{l}\text { Gage height, } \\
\text { in feet }^{3}\end{array}$ & $\begin{array}{l}\text { Calendar } \\
\text { date }\end{array}$ & $\begin{array}{l}\text { Gage height, } \\
\text { in feet }^{3}\end{array}$ & $\begin{array}{l}\text { Calendar } \\
\text { date }\end{array}$ & $\begin{array}{l}\text { Gage height, } \\
\text { in feet }^{3}\end{array}$ \\
\hline $1932^{4}$ & & Not available & & Not available & & Not available & & Not available \\
\hline $1956^{4}$ & & Not available & & Not available & & Not available & & Not available \\
\hline 1973.9 & $12 / 5 / 1973$ & Not available & 2/3/1973 & Not available & $12 / 7 / 1973$ & Not available & $12 / 9 / 1973$ & Not available \\
\hline 1975.7 & $10 / 11 / 1975$ & Not available & $4 / 15 / 1975$ & Not available & $9 / 25 / 1975$ & Not available & $9 / 26 / 1975$ & Not available \\
\hline 1977.4 & 7/2/1977 & Not available & 6/3/1977 & Not available & 1/23/1977 & Not available & 4/6/1977 & Not available \\
\hline 1985.1 & $10 / 11 / 1985$ & 6.79 & $1 / 19 / 1985$ & 5.81 & $1 / 26 / 1985$ & 5.94 & $12 / 3 / 1985$ & 6.30 \\
\hline 1988.1 & $12 / 4 / 1987$ & 6.46 & $1 / 28 / 1988$ & 5.02 & $12 / 2 / 1987$ & 6.33 & 1/26/1988 & 5.97 \\
\hline 1990.8 & $2 / 14 / 1991$ & 5.97 & $11 / 1 / 1990$ & 6.56 & $11 / 24 / 1990$ & 6.40 & $10 / 30 / 1990$ & 6.69 \\
\hline 1995.7 & 10/7/1995 & 6.89 & 9/28/1995 & 6.86 & 10/5/1995 & 6.92 & 9/10/1995 & 6.82 \\
\hline 1998.2 & 2/17/1998 & 6.04 & 2/24/1998 & 5.64 & $3 / 3 / 1998$ & 6.14 & $3 / 10 / 1998$ & 6.17 \\
\hline 1999.9 & 11/27/1999 & 6.36 & $11 / 18 / 1999$ & 6.46 & $11 / 16 / 1999$ & 6.50 & 10/24/1999 & 6.73 \\
\hline 2002.2 & $1 / 3 / 2002$ & 6.00 & $2 / 27 / 2002$ & 5.45 & $2 / 2 / 2002$ & 5.97 & $1 / 8 / 2002$ & 6.00 \\
\hline 2004.9 & $10 / 15 / 2004$ & 6.76 & 11/7/2004 & 6.46 & $10 / 13 / 2004$ & 6.79 & $11 / 5 / 2004$ & 6.59 \\
\hline 2005.8 & $10 / 18 / 2005$ & 6.73 & $10 / 25 / 2005$ & 6.10 & $10 / 16 / 2005$ & 6.66 & $10 / 23 / 2005$ & 6.69 \\
\hline 2006.8 & $1 / 25 / 2007$ & 5.97 & $10 / 28 / 2006$ & 6.53 & $11 / 4 / 2006$ & 6.66 & $12 / 13 / 2006$ & 6.23 \\
\hline 2008.8 & $10 / 26 / 2008$ & 6.82 & $10 / 1 / 2008$ & 6.89 & $10 / 8 / 2008$ & 6.89 & $9 / 29 / 2008$ & 6.89 \\
\hline 2009.8 & $11 / 14 / 2009$ & 6.66 & $11 / 5 / 2009$ & 6.69 & $11 / 12 / 2009$ & 6.66 & $11 / 3 / 2009$ & 6.73 \\
\hline 2010.8 & $10 / 16 / 2010$ & 6.53 & $10 / 7 / 2010$ & 6.30 & $10 / 14 / 2010$ & 6.36 & $10 / 5 / 2010$ & 6.86 \\
\hline
\end{tabular}

'Refer to figure 1. These "path" designations correspond to the Landsat Worldwide Reference System-2 (WRS-2) tiling system.

${ }^{2}$ Decimal dating is a more specific dating system than the calendar year and is used to facilitate statistical analyses. It is derived by dividing the day of the year (in the Julian system) by the number of days in the year.

${ }^{3}$ Elevations provided in station datum.

${ }^{4}$ Calendar dates were not available. 


\section{Land Area Change in Coastal Louisiana from 1932 to 2010}

Table 3. Persistent land loss and land gain in coastal Louisiana by basin, as defined by the Coastal Wetlands Planning, Protection and Restoration Act Program (n.d.) , 1932-2010.

[Land area in square miles]

\begin{tabular}{|c|c|c|c|c|c|c|c|c|}
\hline Basin & $1932-56$ & $1956-73$ & $1973-75$ & 1975-77 & $1977-85$ & 1985-88 & 1988-90 & $1990-95$ \\
\hline & \multicolumn{8}{|c|}{ Loss } \\
\hline Atchafalaya Delta & -4.48 & -1.92 & -1.75 & -0.90 & -0.64 & -0.99 & -1.37 & -1.15 \\
\hline Barataria & -56.46 & -70.98 & -64.21 & -27.94 & -42.81 & -16.80 & -26.30 & -26.76 \\
\hline Breton Sound & -30.94 & -11.34 & -9.95 & -9.58 & -7.97 & -5.67 & -8.28 & -9.64 \\
\hline Calcasieu-Sabine & -8.41 & -66.70 & -17.30 & -15.08 & -9.59 & -6.19 & -4.22 & -6.90 \\
\hline Mermentau & -18.68 & -24.35 & -7.00 & -9.31 & -10.01 & -6.59 & -5.49 & -6.58 \\
\hline Mississippi River Delta & -34.06 & -61.93 & -10.51 & -9.61 & -4.86 & -2.44 & -5.64 & -4.41 \\
\hline Pontchartrain & -34.41 & -32.50 & -12.74 & -12.84 & -9.47 & -6.88 & -9.67 & -11.07 \\
\hline $\begin{array}{l}\text { Teche- } \\
\text { Vermilion }\end{array}$ & -14.68 & -8.40 & -4.43 & -4.22 & -3.06 & -3.23 & -3.23 & -2.81 \\
\hline Terrebonne & -75.28 & -46.25 & -45.65 & -50.87 & -35.11 & -22.97 & -27.54 & -30.63 \\
\hline Total & -277.41 & -324.39 & -173.55 & -140.35 & -123.52 & -71.78 & -92.18 & -99.94 \\
\hline \multirow[t]{2}{*}{ Basin } & $1932-56$ & $1956-73$ & 1973-75 & 1975-77 & $1977-85$ & 1985-88 & 1988-90 & $1990-95$ \\
\hline & \multicolumn{8}{|c|}{ Gain } \\
\hline Atchafalaya Delta & 0.89 & 1.12 & 0.63 & 0.32 & 1.77 & 1.17 & 0.60 & 2.47 \\
\hline Barataria & 1.11 & 0.10 & 0.05 & 0.45 & 0.24 & 0.05 & 0.08 & 0.15 \\
\hline Breton Sound & 1.34 & 0.32 & 0.01 & 0.12 & 0.20 & 0.06 & 0.16 & 0.14 \\
\hline Calcasieu-Sabine & 1.87 & 1.68 & 0.18 & 0.26 & 0.74 & 0.19 & 0.19 & 0.57 \\
\hline Mermentau & 1.71 & 0.57 & 0.12 & 0.10 & 0.28 & 0.13 & 0.53 & 1.16 \\
\hline Mississippi River Delta & 2.43 & 0.50 & 0.95 & 2.34 & 2.52 & 1.10 & 1.06 & 0.67 \\
\hline Pontchartrain & 1.59 & 1.69 & 0.61 & 0.17 & 0.30 & 0.16 & 0.28 & 0.20 \\
\hline $\begin{array}{l}\text { Teche- } \\
\text { Vermilion }\end{array}$ & 1.64 & 0.34 & 0.01 & 0.04 & 0.13 & 0.05 & 0.05 & 0.16 \\
\hline Terrebonne & 2.96 & 0.21 & 0.25 & 0.31 & 0.49 & 0.26 & 0.24 & 0.28 \\
\hline Total & 15.53 & 6.52 & 2.82 & 4.10 & 6.68 & 3.17 & 3.21 & 5.79 \\
\hline
\end{tabular}

${ }^{1}$ Data are rounded to two decimal places; values shown may not add to totals shown. 


\begin{tabular}{|c|c|c|c|c|c|c|c|c|}
\hline 1995-98 & 1998-99 & 1999-2002 & $2002-4$ & 2004-6 & 2006-8 & 2008-9 & 2009-10 & $\begin{array}{c}\text { Total } \\
\text { persistent }\end{array}$ \\
\hline & & \multicolumn{3}{|c|}{ Loss } & \multicolumn{4}{|c|}{ Negative change } \\
\hline-0.83 & -0.49 & -0.39 & -0.51 & -0.37 & -0.66 & -0.01 & -0.02 & -16.49 \\
\hline-16.76 & -17.83 & -9.12 & -8.95 & -13.76 & -15.86 & -3.94 & -3.23 & -421.71 \\
\hline-6.93 & -6.47 & -4.26 & -5.48 & -29.32 & -12.25 & -0.98 & -1.79 & -160.87 \\
\hline-7.15 & -5.19 & -2.85 & -1.59 & -22.00 & -23.74 & -1.30 & -0.72 & -198.94 \\
\hline-5.74 & -3.96 & -4.03 & -2.76 & -22.26 & -6.13 & -0.43 & -0.60 & -134.37 \\
\hline-1.89 & -1.02 & -1.02 & -3.46 & -10.11 & -0.90 & -0.14 & -0.03 & -152.02 \\
\hline-7.85 & -6.68 & -4.20 & -5.70 & -15.14 & -7.24 & -1.26 & -1.60 & -179.25 \\
\hline-3.57 & -3.15 & -1.71 & -3.23 & -3.78 & -4.51 & -0.29 & -0.29 & -64.61 \\
\hline-23.12 & -22.50 & -11.99 & -9.63 & -18.27 & -23.40 & -12.31 & -4.49 & -459.99 \\
\hline-73.83 & -67.29 & -39.57 & -41.30 & -135.02 & -94.69 & -20.65 & -12.77 & $-1,788.24^{1}$ \\
\hline \multirow[t]{2}{*}{ 1995-98 } & 1998-99 & 1999-2002 & $2002-4$ & 2004-6 & 2006-8 & 2008-9 & 2009-10 & $\begin{array}{c}\text { Total } \\
\text { persistent }\end{array}$ \\
\hline & & \multicolumn{3}{|c|}{ Gain } & \multicolumn{4}{|c|}{ Positive change } \\
\hline 0.76 & 4.74 & 0.98 & 1.12 & 2.28 & 2.08 & 3.77 & 5.25 & 29.95 \\
\hline 0.29 & 0.09 & 0.30 & 0.31 & 1.25 & 0.58 & 0.35 & 0.52 & 5.91 \\
\hline 0.38 & 0.20 & 0.31 & 0.27 & 1.15 & 0.59 & 0.29 & 0.49 & 6.03 \\
\hline 0.20 & 0.28 & 0.40 & 0.86 & 0.81 & 0.51 & 0.08 & 0.19 & 9.02 \\
\hline 0.70 & 0.18 & 0.33 & 0.28 & 0.44 & 0.19 & 0.04 & 0.11 & 6.87 \\
\hline 0.83 & 1.62 & 1.43 & 0.63 & 2.62 & 2.52 & 0.37 & 2.16 & 23.74 \\
\hline 0.16 & 0.07 & 0.32 & 0.30 & 1.11 & 0.64 & 0.27 & 0.46 & 8.31 \\
\hline 0.09 & 0.10 & 0.12 & 0.14 & 0.51 & 0.24 & 0.13 & 0.11 & 3.85 \\
\hline 0.40 & 0.76 & 0.47 & 0.37 & 1.67 & 0.67 & 0.66 & 0.43 & 10.42 \\
\hline 3.80 & 8.03 & 4.66 & 4.27 & 11.82 & 8.03 & 5.95 & 9.71 & $104.11^{1}$ \\
\hline
\end{tabular}




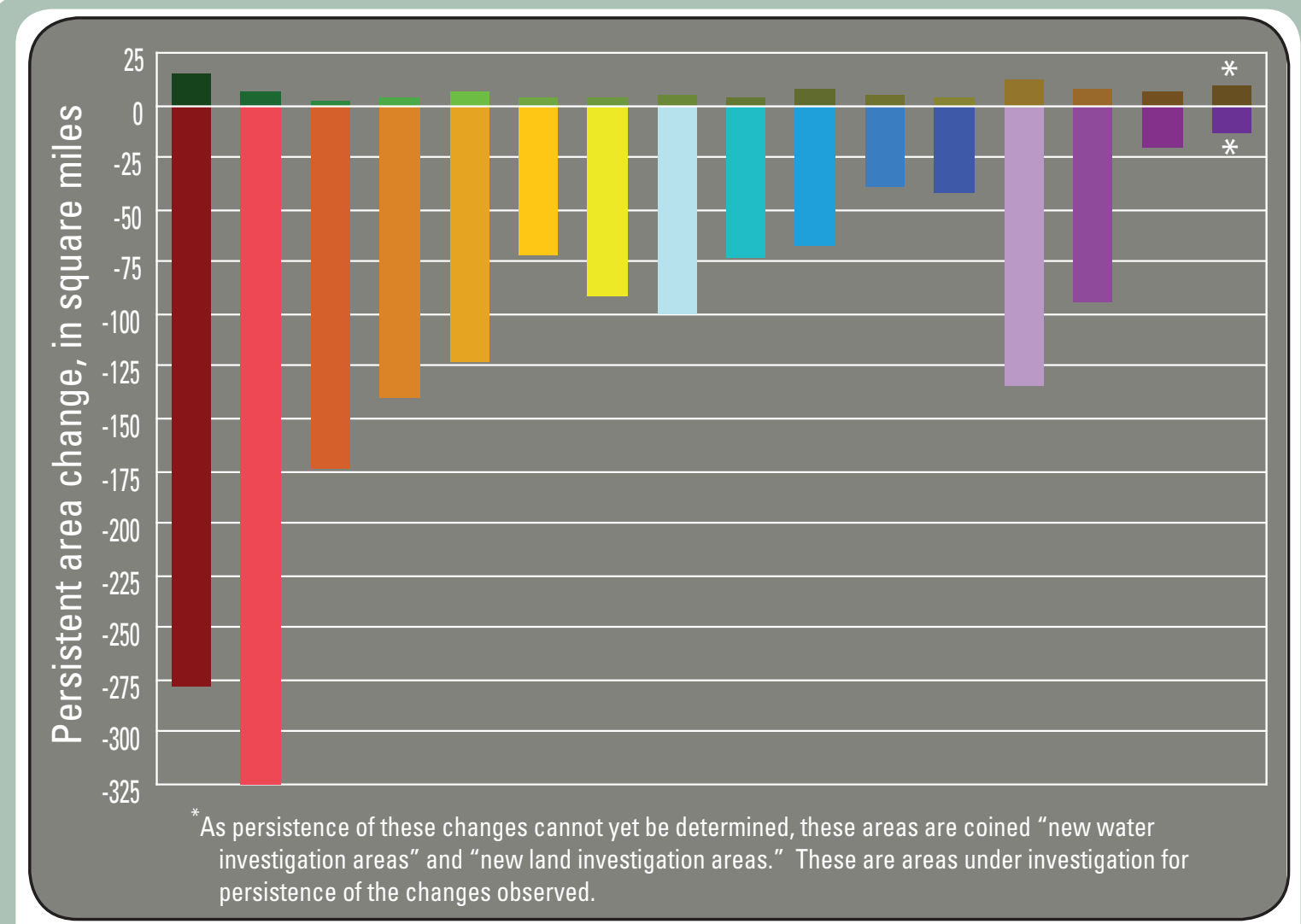

Figure 3. Persistent land loss and land gain across coastal Louisiana by period for 1932-2010.

\section{EXPLANATION}
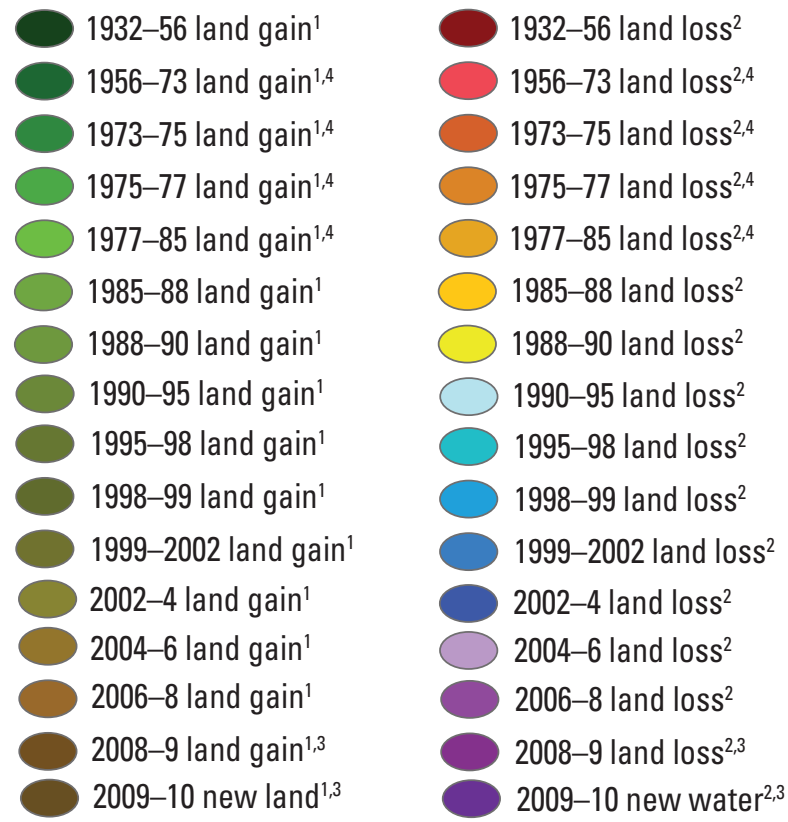

'Gain is determined by the last date a particular pixel transitioned from water to land and remained land throughout the period of observation. ${ }^{2}$ Loss is determined by the last date a particular pixel transitioned from land to water and remained water throughout the period of observation. ${ }^{3}$ Because this date range has only one ending dataset, some of these effects may be temporary phenomena.

${ }^{4}$ This date range contains at least one date in which the land/water data were created from Landsat Multispectral Scanner System (MSS). 


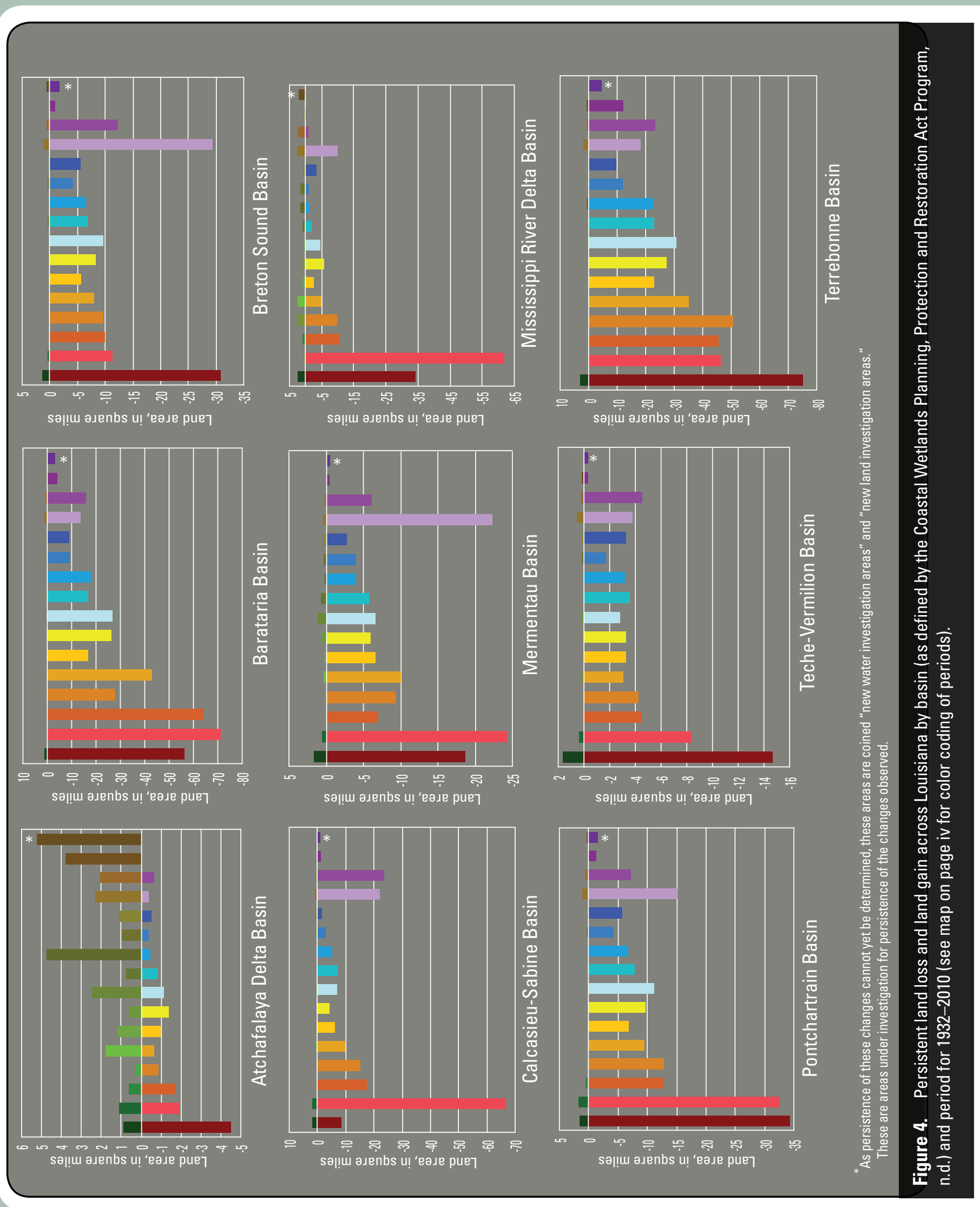


Variability in land area estimates can often be attributed to temporary wind and water level fluctuations present at the date and time of acquisition of the aerial and satellite imagery. Morton and others (2005) found that water area varied by as much as 5 percent over short time periods, largely as the result of environmental variability. The 17 dates of imagery analyzed provide a more robust estimate of change by reducing the inclusion of land area fluctuations caused by environmental variability.

The desire to reduce errors associated with environmental variability was a driving force behind the development of the persistence criteria utilized in this analysis. An area must experience a change in land/water category, and that change must persist for at least two time periods following the initial conversion before that area is classified as "loss" or "gain". The temporal resolution, as well as the persistence criteria used in this analysis, ensures that the data presented are more likely to represent permanent changes compared to previous studies; however, it is important to note when examining wetland loss/gain by time period that wetland areas often fluctuate between land and water categories. These fluctuations can take place for multiple time periods prior to a persistent conversion of an area from land to open water or, conversely, from open water to land. Consequently, loss that is shown to have occurred in a specific time period may have begun that transition in an earlier period. Initial losses often recover temporarily, only to be lost again because of a secondary or compound stressor. With the exception of anomalies, this assessment documents the last time period in which the persistent conversion occurred as opposed to the first time a change was documented.

These analyses have shown that episodic events, such as hurricanes and other extreme storms, have contributed significantly to coastal land loss, particularly in recent years. Annual rates of coastal land loss for 1985 to 2010 (-16.57 \pm $3.26 \mathrm{mi}^{2} / \mathrm{yr}$ ) increased by approximately $4.8 \mathrm{mi}^{2} /$ year relative to the 1985 to 2004 trends $\left(-11.76 \pm 4.47 \mathrm{mi}^{2} / \mathrm{yr}\right)$, reflecting hurricane-induced acceleration of coastal land loss. This is consistent with previous analyses described in Barras and others (2008). In addition to the immediate loss caused by

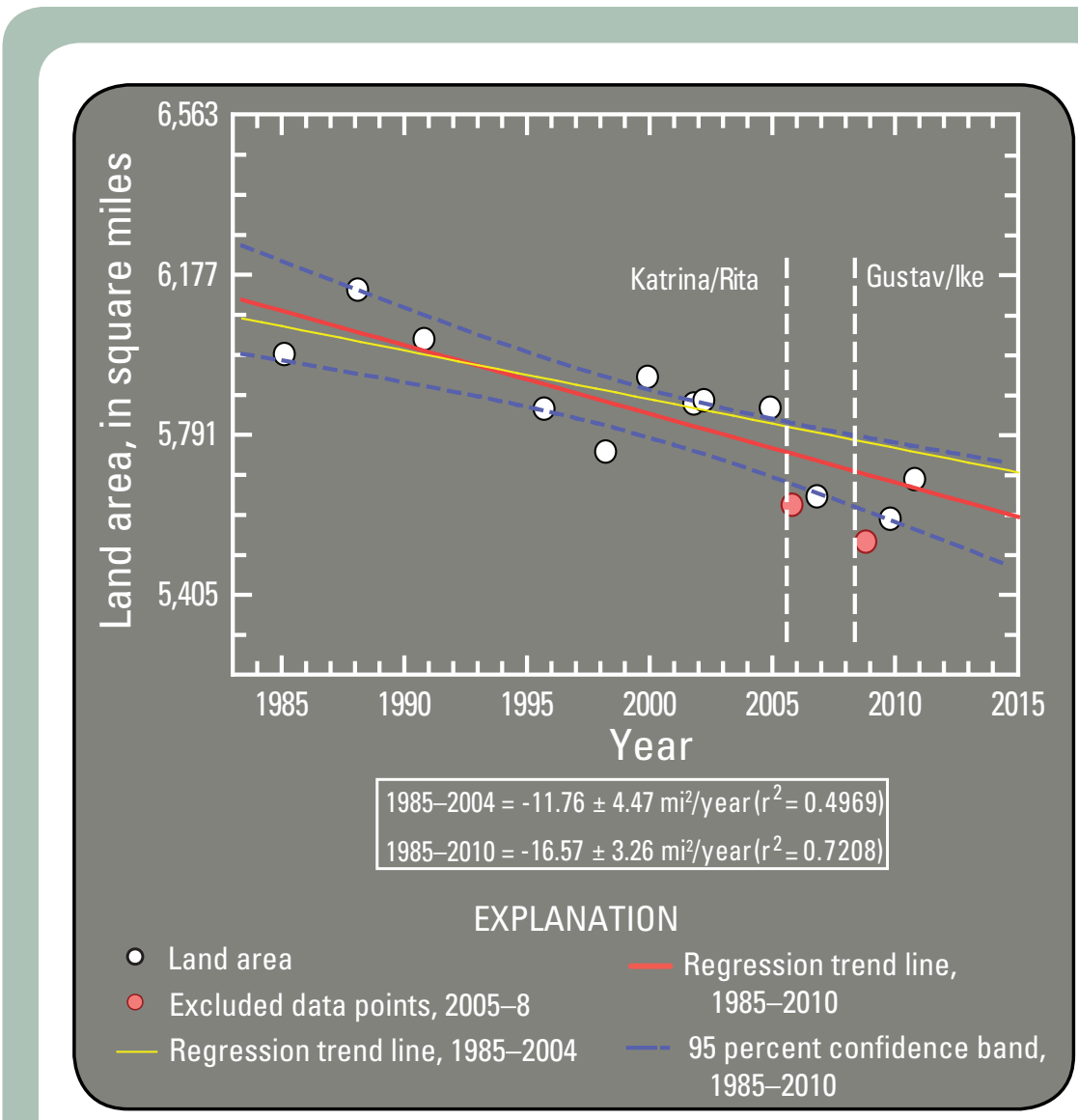

Figure 5. Linear regressions of land area change trends coastwide across Louisiana, 1985-2010; negative measurements indicate land loss, while positive measurements indicate land gain. Rates including and excluding the effects of the hurricanes of 2005 and 2008 are shown for comparison. 


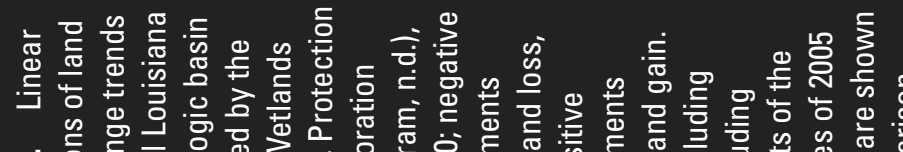
ம

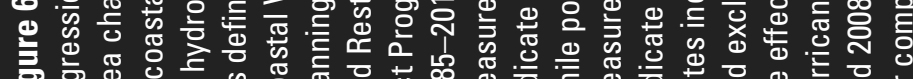

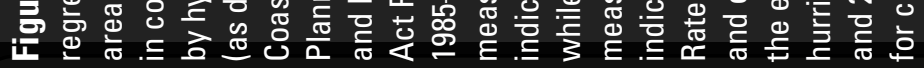
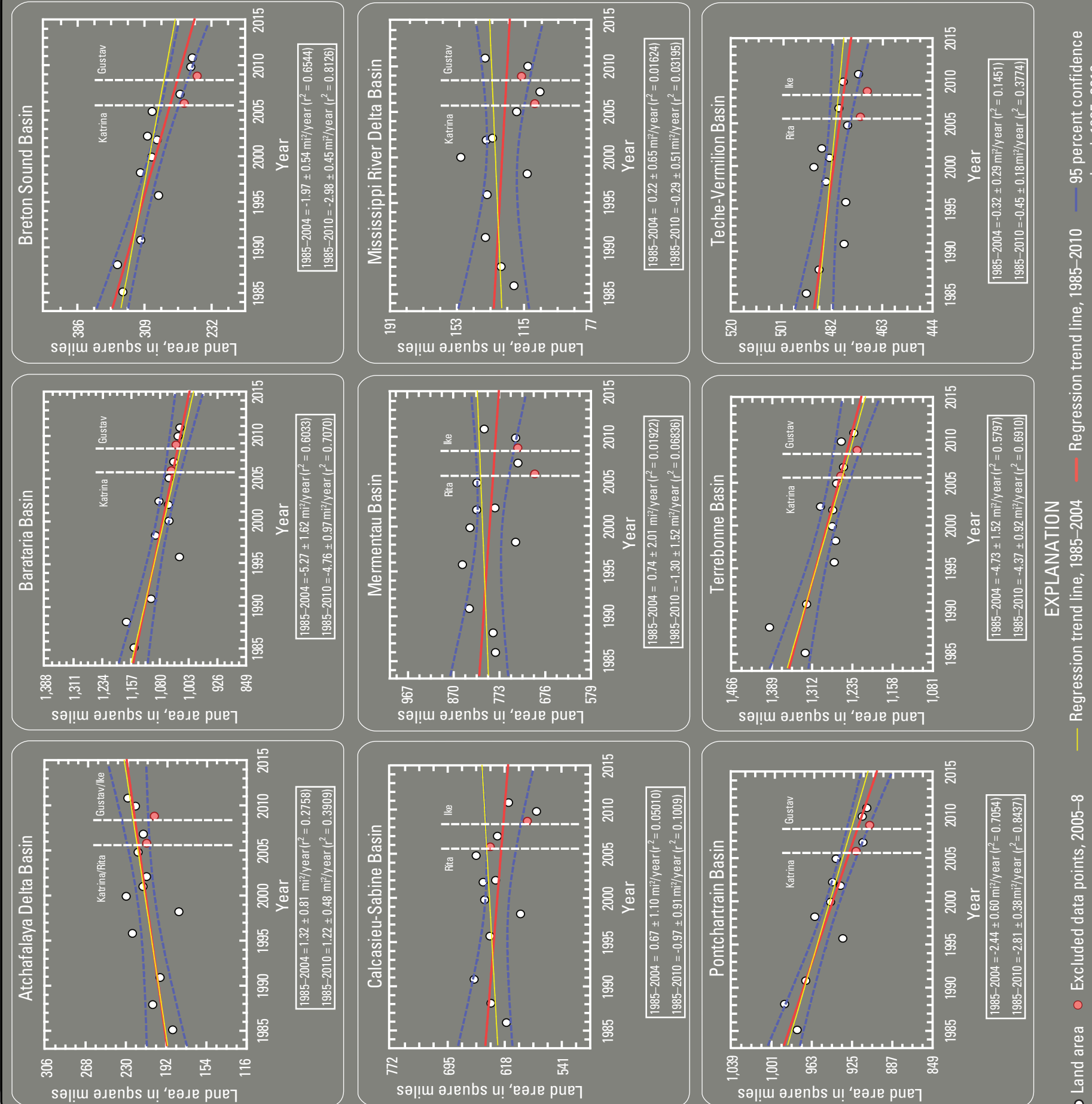

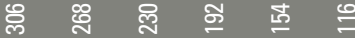
sə|!แ әлеnbs u! 'еәле риеך 
direct physical impacts, hurricanes have been observed to induce excessive plant stress, such as from storm-driven elevated salinity and sulfides (Steyer and others, 2010), which has been suggested to contribute to future wetland losses. This analysis has shown areas that were not immediately observed as loss following a particular storm's landfall, but those areas began to consistently appear as water several months later. Storm-induced stress likely contributed to at least some of the observed losses.

Excluding the high rates of wetland loss due to recent hurricanes, rates of wetland loss had been decreasing from the high rates observed in the 1970s. Britsch and Dunbar (1993) observed a similar trend of decreasing loss after 1978. Though the wetland loss in coastal Louisiana is a dire situation, this observed decrease is at least a measured source of positive news, as past trends are often indicative of potential future losses.

An interesting finding of this analysis may be observed in the increase in net land area in the 2009 and 2010 datasets, as seen in figure 2. Though it may be intuitive to interpret this land area increase as recovery from the low, hurricaneinfluenced land area estimates of 2008, the potential influence of environmental variability dictates caution before interpreting this pattern as "recovery." Discriminating the permanence of these increases from the transitory effects of environmental variability may require several additional years of observations.

The temporal frequency of land change provided by this study is allowing scientists to further investigate the causal mechanisms of the loss that has occurred. These investigations will provide improved information to develop tools to monitor ecosystems, forecast possible impacts, and plan protection and restoration activities. These data can help support the development of strategies to adapt to our changing environment.

\section{References}

Barras, J.A., 2006, Land area change in coastal Louisiana after the 2005 hurricanes-A series of three maps: U.S. Geological Survey Open-File Report 2006-1274. (Also available at http://pubs.usgs.gov/of/2006/1274/.)

Barras, J.A., 2007, Land area changes in coastal Louisiana after Hurricanes Katrina and Rita, in Farris, G.S., Smith, G.J., Crane, M.P., Demas, C.R., Robbins, L.L., and Lavoie, D.L., eds., Science and the storms-the USGS response to the hurricanes of 2005: U.S. Geological Survey Circular 1306, p. 97-112. (Also available at http://pubs.usgs.gov/ circ/1306/.)
Barras, J.A., Bernier, J.C., and Morton, R.A., 2008, Land area change in coastal Louisiana-A multidecadal perspective (from 1956 to 2006): U.S. Geological Survey Scientific Investigations Map 3019, scale 1:250,000, 14 p. pamphlet. (Also available at http://pubs.usgs.gov/sim/3019/.)

Bernier, J.C., Morton, R.A., and Barras, J.A., 2006, Constraining rates and trends of historical wetland loss, Mississippi River delta plain, south-central Louisiana, in $\mathrm{Xu}$, Y.J., and Singh, V.P., eds., Coastal environment and water quality-Proceedings of the AIH 25th Anniversary Meeting and International Conference Challenges in Coastal Hydrology and Water Quality: Highlands Ranch, Colo., Water Resources Publications, LLC, p. 371-373. (Also available at http://coastal.er.usgs.gov/gc-subsidence/ historical-wetland-loss.html.)

Britsch, L.D., and Dunbar, J.B., 1993, Land-loss ratesLouisiana coastal plain: Journal of Coastal Research, v. 9, p. 324-338.

Britsch, L.D., and Dunbar, J.B., 2006, Land loss in coastal Louisiana 1932 to 2001-A series of maps: Vicksburg, Miss., Engineer Research and Development Center, U.S. Army Engineer District, New Orleans.

Louisiana Coastal Wetlands Planning, Protection and Restoration Act Program, n.d., Coastal Louisiana basins: Louisiana Coastal Wetlands Planning, Protection and Restoration Act Program Web site, accessed May 5, 2011, at http://lacoast.gov/new/About/Basins.aspx.

Morton, R.A., Bernier, J.C., Barras, J.A., and Fernia, N.F., 2005, Rapid subsidence and historical wetland loss in the Mississippi Delta Plain, likely causes and future implications: U.S. Geological Survey Open-File Report 2005-1216, 124 p. (Also available at http://pubs.usgs.gov/ of/2005/1216/.)

Steyer, G.D., Cretini, K.F., Piazza, Sarai, Sharp, L.A., Snedden, G.A., Sapkota, Sijan, 2010, Hurricane influences on vegetation community change in coastal Louisiana: U.S. Geological Survey Open-File Report 2010-1105, 21 p. (Also available at http://pubs.usgs.gov/of/2010/1105/.)

Publishing support provided by the USGS Lafayette Publishing Service Center 
